\begin{tabular}{|c|c|c|c|c|c|c|}
\hline \multirow{4}{*}{ Impact Factor: } & ISRA (India) & $=4.971$ & SIS (USA) & $=0.912$ & ICV (Poland) & $=6.630$ \\
\hline & ISI (Dubai, UAE & $=0.829$ & РИНЦ (Russia) & $=0.126$ & PIF (India) & $=1.940$ \\
\hline & GIF (Australia) & $=0.564$ & ESJI (KZ) & $=8.716$ & IBI (India) & $=4.260$ \\
\hline & JIF & $=1.500$ & SJIF (Morocco) & $=5.667$ & OAJI (USA) & $=0.350$ \\
\hline
\end{tabular}

\section{SOI: $1.1 /$ TAS $\quad$ DOI: $10.15863 /$ TAS \\ International Scientific Journal Theoretical \& Applied Science}

p-ISSN: 2308-4944 (print)

e-ISSN: 2409-0085 (online)

Year: 2020

Issue: 03

Volume: 83

Published: 25.03 .2020

http://T-Science.org
QR - Issue

QR - Article
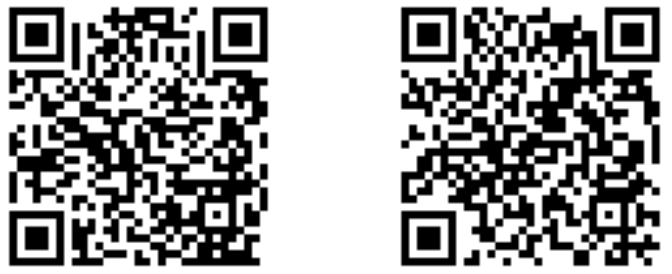

Qunduz Sobirovna Mustaqimova

The Bukhara Engineering and technological institute A teacher of

The "Uzbek language and literature" department

\title{
PECULIAR FEATURES OF THE MODERN MEDIA LANGUAGE
}

Abstract: one of the peculiarities of advertising texts is the use of command verbs in advertising texts. For example, feel, visit, enjoy, get to know, choose, wait, join, enjoy, hurry, and so on. It is also important to note that the visual language of the type of visual advertising is important and lively and can be conveyed to the reader in an impressive manner. In other words, advertising should combine language units and visual arts. Visual advertising can be divided into advertising with linguistic text and non-linguistic text, depending on whether or not language units are used. Linguistic text advertising carry more information than advertising without linguistic text. The achievement of the intended purpose in linguistic text advertising also depends on the choice of key words that represent the content of the advertisement, their shortness, form, color and other features.

Key words: advertising, primary and main element of advertising, street advertising language, captions, slogans, posters, media linguistics.

Language: English

Citation: Mustaqimova, Q. S. (2020). Peculiar features of the modern media language. ISJ Theoretical \& Applied Science, 03 (83), 108-110.

Soi: http://s-o-i.org/1.1/TAS-03-83-23 Doi: crosłef https://dx.doi.org/10.15863/TAS.2020.03.83.23

Scopus ASCC: 1203.

\section{Introduction}

Without linguistic text, language units are virtually non-existent. Various symbols, images and nolinguistic tools are at the heart of such advertising. All of the linguistic and nolinguistic tools used to provide information form an advertising text. What is known to the buyer is that all the tools that inform the process are an integral part of the text. However, in text-free advertisements, the buyer may not understand what is being displayed unless the buyer is partially informed about the product.

One of the peculiarities of visual advertising texts is that their texts are concise, meaningful, and lively. In these promotional texts, words are usually composed of simple words and often consist of words and incomplete sentences. In general, the text of the visual advertising is quite different from the other texts, depending on the structure and extent of usage of linguistic units. When designing an advertising text, it is advisable to create advertising texts based on the nature of that language. The exact translation of advertising texts created in other languages does not always have the desired effect.

\section{II.Analysis}

Since the main purpose of advertising in social life is selling, this process must, of course, be done with grounded texts. In this sense, we can say that as a linguistic unit, advertising slogans also play an important role in the economy. The main thing is that the advertising text must inform and reassure. In the opinion of E.D. Farbi, the advertising text may be subdivided into:

1. Ktematonim (gr. Kteto "property" + otta "name") is word expression of trademark.

2. Slogan ("slogan" - motto) is a short slogan representing the advertising of the brand. A short, clear and easy-to-remember expression.

The Russian copywriter V.I.Maksimova as follows: the function of the advertised goods in the society is to express the idea, the content in a concise and descriptive form. This information can be expressed in one or two sentences. Indeed, we can say that this is valid.

The advertising slogan is the main element of the advertising. Members of the public decide whether to read the entire text of the advertisement under the banner. Because the taste of life !. After reading the 


\begin{tabular}{|c|c|c|c|c|c|c|}
\hline \multirow{4}{*}{ Impact Factor: } & ISRA (India) & $=4.971$ & SIS (USA) & $=0.912$ & ICV (Poland) & $=6.630$ \\
\hline & ISI (Dubai, UAE & $=0.829$ & РИНЦ (Russia & $=0.126$ & PIF (India) & $=1.940$ \\
\hline & GIF (Australia) & $=0.564$ & ESJI (KZ) & $=8.716$ & IBI (India) & $=4.260$ \\
\hline & JIF & $=1.500$ & SJIF (Morocce & $=5.667$ & OAJI (USA) & $=0.350$ \\
\hline
\end{tabular}

slogan, people today know that it is Coco Cola and do not read the entire text. According to R. Rivz, a specialist in advertising, the consumer will only remember one clear statement or one clear statement from the text of the advertisement.

Advertising is a process that is encountered every day and everywhere. Advertising penetrates all areas of mass communication. Promotional text must be:

- composing meaningful text using short phrases, short sentences, and short paragraphs; headline;

- to prove the advertised proposal directly in the

- repeat the text below the title;

- transfer of advertising text with moving pictures of a product or service;

- entering a statement on the soundness of the proposal;

- write the word or phrase in capital letters.

Terms in the advertising texts. All promotional texts are composed of many elements or components. These elements can be mixed, exaggerated, reduced, replaced, or removed until something unique occurs. The most important elements of a printed announcement; title, visuals, headings, main text, quotes, frames, slogans, logos, facts, notes. The title is the most important element of a print announcement. Therefore, the title should be visible and appealing. The title is typed in capital letters.

The title has 6 main functions:

1) it must be attentive;

2) be able to choose its own consumer (good's consumer);

3) the title should direct a person to something, including the reader to the main text; then the commercial idea must be fully reflected; goods;

4) the title must promise the benefit of buying the

5) the title should reflect the news that is interesting to the reader.

6) important detail: according to the expert, people read the headline 5 times more than the text of the advertising. So much depends on the title.

There are many types of headings. Titles can be divided into 5 main types:

1) interested - the reader is interested, he wants to know more and reads the text.

2) information type - here is new information and it is called "how to do it" (know, buy, etc.).

3 ) interrogation - is widely used, but there is a risk of abuse of this method. If the reader easily or negatively answers the question, the chances of him reading the promotional text are reduced.

4) about the useful properties of the product is a direct reference to the useful properties of the product.

5) command tone - Commands to do something. It's not always bad.

5 key requirements:

- the main idea needs to be emphasized;
- it is necessary to clearly indicate the brand's location;

- consumers should note that it is useful;

- the brand name is highlighted and

strengthened;

- the text is clear and concise;

The following are some of the common ways to promote your advertising text:

- to report facts directly;

- self-description;

- adding dialogue - monologues, illustrations; - original genre.

The direct statement follows from the information contained in the headlines and captions, with the importance of brand characteristics. The narrative text tells all the events, takes into account a problem and tells you how to solve it. In selfdefinition, it is important to avoid excessive selfpraise.

Dialogue-monologue style helps to eliminate mistrust. Experience of a playwright is required. The idea of selling is conveyed by participants' words or performances. Illustrating storytelling involves the use of visual material. Advertising can use a different style or other genre.

The text consists of 4 basic elements:

- Access paragraph;

- Internal paragraphs;

- Intermediate code;

- Code.

The access paragraph turns the reader's interest into the product.

The internal paragraphs increase the interest in the goods, for this the advertising must be fair, and the confidence should be given.

Intermediate paragraphs mean filling the desire to order. There are several ways in which a good promotional text is available.

Code - at the end of the advertisement is addressed to the consumer and how to do it. This place in the advertisement is, in fact, the same point of sale of the goods.

The code can be in the form of a direct quote, direct or indirect.

Blankets and frames... Slogans... Seals, logos and handwriting.

\section{III.Conclusion}

Advertising:

- the cheapest way to find a buyer for a product or service;

- to create and disseminate the idea about the goods service, there by stimulating the consumer to buy it;

- the way to sell a success;

- increasing the demand for the goods and services by attracting the consumer's attention;

- a persuasive product of goods, services, or profits is a commercial propaganda about the 


\begin{tabular}{|c|c|c|c|c|c|c|}
\hline \multirow{4}{*}{ Impact Factor: } & ISRA (India) & $=4.971$ & SIS (USA) & $=0.912$ & ICV (Poland) & $=6.630$ \\
\hline & ISI (Dubai, UAE & $=0.829$ & РИНЦ (Russia & $=0.126$ & PIF (India) & $=1.940$ \\
\hline & GIF (Australia) & $=0.564$ & ESJI (KZ) & $=8.716$ & IBI (India) & $=4.260$ \\
\hline & JIF & $=1.500$ & SJIF (Morocec & $=5.667$ & OAJI (USA) & $=0.350$ \\
\hline
\end{tabular}

consumer characteristics of goods and services, preparing potential buyers for the purchase.

The conclusion is that the text should be clear, meaningful, interesting, authentic, exciting, elegant and memorable.

\section{References:}

1. Ogilvi, D. (2009). Tajny reklamnogo dvora. (p.145). Retrieved from www.koob.ru

2. Farbi, Je.D. (2004). Kak sozdat' usreshnuju reklamu. (p.123). SPb..

3. (2004). Stilistika i litiraturnoe redaktirovanie. Pod.red.prof. Maksimova V.I. (Ed.). (p.158). Moscow.

4. Medvedeva, E.V. (2003). Reklamnaja propaganda, ili "pochem opium dlja naroda". Vestnik $M G U$, p. 27.

5. (n.d.). Retrieved from info@zipwolf.com

6. Aybeshov, H., et al. (2013). Marketing asoslari. Tashkent: "ILM ZIYO".

7. Dobrosklonskaja, T.G. (2008). Medialingvistika: sistemnyj podhod $k$ izucheniju jazyka SMI: sovremennaja anglijskaja mediarech'. Moscow: Flinta: Nauka.
8. Dejk, Teun van. (2000). Jazyk. Poznanie. Kommunikacija. B.: BGK im. I. A. Bodujena de Kurtenje.

9. Mol', A. (1973). Sociodinamika kul'tura. Moscow.

10. Boyd-Barret, O. (1997). Media Imperialism: Towards an international framework for an analysis of media systems. Ch. 5 in Mass Communication and Society. London.

11. Phillipson, R. (1992). Linguistic Imperialism. London.

12. (2005). Jazyk sovremennoj publicistiki. Sb.statej / Po red. G.Ja.Solganika (Ed.). Moscow: Flinta: Nauka.

13. Matveyev, B.G. (1998). "Iqtisodiy bilim asoslari". Tashkent: "Sharq". 